УДК $821.111-31$

DOI: $10.15421 / 3820019$

\author{
T. Kyrpyta \\ Т. В. Кирпита \\ Т. В. Кирпита
}

National Metallurgical Academy of Ukraine

Начіональна металургійна академія Украӥни

Начиональная металлургическая академия Украинь

\title{
THE UNCANNY IN «CARMILLA» BY J. S. LE FANU IN THE CONTEXT OF NIETZSCHEAN AND PSYCHOANALYTIC PERCEPTION
}

\author{
МОТОРОШНЕ У «КАРМІЛЛІ» ДЖ. Ш. ЛЕ ФАНЮ У КОНТЕКСТІ \\ НЦЩШЕАНСЬКОГО ТА ПСИХОАНАЛІТИЧНОГО СПРИЙНЯТТЯ
}

\author{
ЖУТКОЕ В «КАРМИЛЛЕ» ДЖ. Ш. ЛЕ ФАНЮ В КОНТЕКСТЕ \\ НИЦШЕАНСКОГО И ПСИХОАНАЛИТИЧЕСКОГО ВОСПРИЯТИЯ
}

The article deals with the category of uncanny as an integral part of Gothic literature in the aspect of philosophical and aesthetic views. It traces the connection between the notions of «horrible», «ugly» and "sublime», as well as the artistic embodiment of this connection in the novella about the vampires «Carmilla» by J.S. Le Fanu.

Sigmund Freud's article «The Uncanny» gave literary critics one of the key concepts that are used in the analysis of Gothic literature and literature of horror. The Uncanny, according to Freud is something strange, which disguises itself as a familiar one, it is something that should be hidden, but suddenly showed itself. In Gothic, this is usually embodied in anthropomorphic objects that resemble humans (or other living creatures), but are not in truth: dolls, mechanical toys, art images, etc. That is, the things acquire properties unusual and uncharacteristic for them.

At the heart of the horror literature as a successor to a Gothic novel lays the idea of the wrongness and disharmony. In this context, Freud's «uncanny» echoes the Kantian notion of «sublime», as well as, to a certain extent, the paradox of the ugly put forward by N. Goodman. Kant's «sublime» is aesthetically close to Freud's «uncanny». This is something recognisable and at the same time immense, which gives a sense of grandeur and even holiness, and hence, causes surprise, connected with awe and fear. The ideal content of the sublime is far greater than its real embodiment.

Following F. Nietzsche, who advocated aesthetic relativism and considered the irrational Dionysian impulse to be no less important than the rational Apollonian one, the postmodernists rejected the aesthetic distinction between Good and Evil and, consequently, the contrast between the Beautiful and the Ugly. Thus, N. Goodman, in his paradox of the ugly, says that under certain circumstances ugly objects can be perceived as attractive ones, and the beautiful arouses disgust. And $\mathrm{J}$. Kristeva believes that it is through disgust caused by the ugly that catharsis occurs as purification from existential fear.

We traced the features of the artistic embodiment of horror, disgust and uncanny in «Carmilla» by J. S. Le Fanu.

Keywords: uncanny, ugly, beautiful, sublime, literary gothic, literature of horrors.

Розглянуто категорію моторошного як невід’смної складової готичної літератури в аспекті філософсько-естетичних поглядів. Прослідковано зв'язок між поняттями «жахливе», «потворне» і «піднесене», а також художнє втілення цього зв'язку у новелі про вампірів Дж. Ш. Ле Фаню «Кармілла».

Стаття Зигмунда Фройда «Моторошне» подарувала літературознавцям одне з ключових понять, яким оперують при аналізі готичної літератури та літератури жахів. Моторошне, за Фройдом, - це чужорідне, що маскусться під знайоме, це те, що мало б бути прихованим, але несподівано виявило себе. У готиці це зазвичай втілено в антропомор-

(C) Kyrpyta T., 2020 
фних об’сктах, що здаються людиною (або іншою живою істотою), але не с нею: ляльки, механічні іграшки, художні зображення та ін. Тобто речі набувають незвичайних, не притаманних їм властивостей.

В основі літератури жахів як наступниці готичного роману лежить ідея неправильності, дисгармонії. У цьому контексті «моторошне» Фройда перегукусться з кантівським поняттям «піднесеного», а також певною мірою - 3 парадоксом потворного, висунутим Н. Гудменом. «Піднесене» Канта с естетично близьким до «моторошного» Фройда. Це щось, що ми усвідомлюємо, і водночас неосяжне, що дає відчуття величності й навіть святості, і звідси, викликас здивування, пов'язане з благоговінням і страхом. Ідеальний зміст величного значно більший ніж його реальне втілення.

Слідом за Ф. Ніцше, який виступав за естетичний релятивізм і вважав ірраціональне діонісійське начало не менш важливим, ніж раціональне аполлонівське, постмодерністи відкидали естетичне розмежування Добра і Зла i, відповідно, протиставлення Прекрасного і Потворного. Так, у парадоксі потворного Н. Гудмена йдеться про те, що за певних обставин потворні об'скти можуть сприйматися як привабливі, а прекрасне викликати огиду. А Ю. Кристсва вважас, що саме через огиду, викликану потворним, відбувасться катарсис як очищення від екзистенціального страху.

Ми простежили особливості художнього втілення жаху, огиди і моторошного у новелі Ле Фаню «Кармілла».

Ключові слова: моторошне, потворне, прекрасне, піднесене, літературна готика, література жахів.

Рассмотрена категория жуткого как неотьемлемая составляющая готической литературы в аспекте философско-эстетических взглядов. Прослежена связь между понятиями «ужасное», «безобразное» и «возвышенное», а также художественное воплощение этой связи в новелле о вампирах Дж. Ш. Ле Фаню «Кармилла».

Статья Зигмунда Фрейда «Жуткое» подарила литературоведам одно из ключевых понятий, которым оперируют при анализе готической литературы и литературы ужасов. Жуткое, по Фрейду, - это чужеродное, которое маскируется под знакомое, это то, что должно быть скрытым, но неожиданно проявило себя. В готике это обычно воплощено в антропоморфных объектах, кажущихся человеком (или другим живым существом), но им не являющихся: куклах, механических игрушках, художественных изображениях и др. То есть вещи приобретают необычные, не характерные для них свойства.

В основе литературы ужасов как преемницы готического романа лежит идея неправильности, дисгармонии. В этом контексте «жуткое» Фрейда перекликается с кантовским понятием «возвышенного», а также в определенной степени - с парадоксом безобразного, выдвинутым Н. Гудменом. «Возвышенное» Канта эстетически близко к «жуткому» Фрейда. Это осознаваемое и в то же время необъятное, которое дает ощущение величия и даже святости, и отсюда, вызывает удивление, связанное с благоговением и страхом. Идеальное содержание возвышенного значительно больше, чем его реальное воплощение.

Вслед за Ф. Ницше, который выступал за эстетический релятивизм и считал иррациональное дионисийское начало не менее важным, чем рациональное аполлоновское, постмодернисты отвергали эстетическое разграничение Добра и Зла и, соответственно, противопоставление Прекрасного и Безобразного. Так, Н. Гудмен в парадоксе безобразного говорит о том, что при определенных обстоятельствах уродливые объекты могут восприниматься как привлекательные, а прекрасное вызвать отвращение. А Ю. Кристева считает, что именно через отвращение, вызванное уродливым, происходит катарсис как очищение от экзистенциального страха.

Мы проследили особенности художественного воплощения ужаса, отвращения и жуткого в новелле Ле Фаню «Кармилла».

Ключевые слова: жуткое, безобразное, прекрасное, возвышенное, литературная готика, литература ужасов.

The tale starts with meditations about «our dual existence and its intermediates» [5, p. 207]. Although Le Fanu does not deliberately explain the essence of this statement, leaving his interpretation at the discretion of the reader, we can assume that it is a matter of life and death, since the latter was regarded by the mystics as another form of existence. 
The intermediate state here is vampirism, since a vampire no longer belongs to the world of the living, but is not dead in the fullest sense. It is a being that indeed lives a dual life: it pretends to be alive at a time when it is no longer alive and deceives death without giving in to it completely. This character differs from a ghost or double (Doppelgänger) by his emphasized physicality and, at the same time, by his supernatural abilities, as well as by the fact that he chooses his victim, that is, manifests his will.

Here we deal with one of the key means of the Gothic - the uncanny. This term appeared for the first time in an article by Sigmund Freud entitled «The Uncanny» (1919). The basic idea was that we are not terrified of what seems to us unknown, alien, but rather, of what seems familiar. In Gothic prose, one of the most formidable embodiments of uncanny is anthropomorphic creatures and human-like objects like dolls, wax statues, or mechanical toys. This series can be continued with such images of «mystical» literature, such as ghost, vampire, double/ Doppelgänger. The psychoanalytic notion of the uncanny echoes with two other philosophical categories: the «sublime» of Immanuel Kant and the «paradox of the ugly» described by Nelson Goodman.

Kant's sublime is an aesthetic category that expresses the intrinsic significance of objects and phenomena that, by their ideal content, go far beyond the real forms of their expression. It is something that we are aware of and that gives us a sense of its grandeur or even holiness [3, p. 173]. This concept is much broader than the concept of beauty, it is associated with a sense of inaccessibility and outreach, and hence it causes awe and even fear. Aesthetically, it is related to Freud's uncanny, which also appeals to strangeness, a sense of horror from supposedly familiar objects that manifest themselves from an unexpected side. The very word «unheimlich» in German is at the same time the lexical antonym of the word «heimlich» («secret») and contains the root «Heim» («house»). That is, it is something that does not want to remain hidden, and at the same time goes beyond the «home», that is, the familiar environment. Thus, Freud's «unheimlich» is not only «terrifying» but also «incredible»; here the unusual (fantastic) is disguised as a mundane. Freud himself quotes Schelling, who says that «everything is uncanny that ought to have remained hidden and secret, and yet comes to light» [2, p. 420].

The uncanny in Le Fanu's novel is the figure of the title character herself. She looks just like a normal person, although a bit flaccid - the image of Le Fanu's vampire has not yet acquired the characteristic faintness and expressive fangs (they will appear a little later, in «Dracula» by Stoker). At the same time, she is not entirely a human being. She is the inanimate one who came to life. To paraphrase Schelling's words, Carmilla ought to have been buried, and yet she rises from the dead and declares herself.

Edmund Burke came up with the idea of the connection between the fearful and the sublime in his treatise «A Philosophical Enquiry into the Origin of Our Ideas of the Sublime and Beautiful» (1757), stating that fear in all cases, whether openly or secretly, is the guiding principle of the sublime [1, p. 58]. Thus, in the fiction of horror the sublime loses harmony and beauty, it is rather fearsome and irresistible. In fact, at the origins of Gothic literature is the idea of irregularity or abnormality, disharmony as opposed to «correct», harmonious classical tradition.

This irregularity brings us to yet another category of aesthetics - the ugly. Contrary to the ancient notion of the ugly as the antipode of the beautiful the nineteenth-century philosopher Karl Rosenkranz suggested that beauty lies in the middle between the infinitely majestic and the ultimate pleasant associated with the form, while the ugly occupies an intermediate position between the beautiful and the comic [6, p. 95]. The romantics considered the reverse of the beautiful no less significant and, unlike the 
classicists, paid much attention to the chaotic, the amazing, the wonderful and fantastic, the sublime and ugly. Nietzsche generally advocated aesthetic relativism, calling for the reassessment of all traditional values. He was ambiguous about the beautiful. On the one hand, he attributes beauty to the antiaristocratic culture he idealizes. On the other hand, he sees it as an illusion created by the artist-god and embodied in the culture based on Apollo's rationalized principle as the main principle that governs and transforms the world. At the same time, Nietzsche demands the legitimization of a productive irrational chthonic impulse - the Dionysian one, believing that it carries a vital impulse that is lacking in European culture for the emergence of «the superman» [3, p. 180]. Thus, the Nietzschean juxtaposition of the Apollonian and Dionysian impulses was a continuation of the «classical-romantic» opposition.

J. Kristeva, in her work «Powers of Horror: An Essay on Abjection» (French: «Pouvoirs de l'horreur. Essai sur l'abjection», 1980), states that the two categories (horror and abjection) are closely related. According to this point of view, human body fluids and their equivalents (rot, infection, disease, corpse, etc.), as Kristeva points out, is a danger originating from the outside of identity: I feel threatened by Not-Me, society is threatened by its outside, life threatens death [4, p. 260].

In fact, in horror literature, the primary threat to the body is death, and the reader is confused by the physiological danger: pain, illness, and decease. Moreover, since within this genre there are two worlds, before and after death, those who died in a «wrong» way (suicides, vampire victims, unjustly executed, etc.) can manoeuvre between these worlds, being in the afterlife, now and then returning to the world of the living.

Being a vampire, Carmilla is an unnatural creature, and Laura notices her «irregularity», that is why, along with admiration for her beauty and refined manners, she immediately feels abomination: «I experienced a strange tumultuous excitement that was pleasurable, ever and anon, mingled with a vague sense of fear and disgust. I had no distinct thoughts about her while such scenes lasted, but I was conscious of a love growing into adoration, and also of abhorrence.» [5, p. 225].

Therefore, Carmilla is both attractive and repelling, and Laura, along with the passion and love that grows into adoration, feels the fear and disgust that grow into disgust and horror.

Thus, at the level of the text, the concept of horrible is embodied with the words belonging to the lexico-semantic fields «death», «pain», «horror» and «disgust», expressed with the help of lexico-stylistic means.

Hereinafter, it is Carmilla's talk of death that frightens Laura. Carmilla speaks of death as a rebirth, a transition to another form of existence, where she and Laura will be together:

"You must come with me, loving me, to death; or else hate me and still come with me, and hating me through death and after» [5, p. 236].

Herewith Carmilla states that love demands bloody sacrifice:

«Love will have its sacrifices. No sacrifice without blood» [5, p. 236].

Laura calls her strange sickness after the vampire outbreak «a very strange agony» [5, p. 237]. In the night when Carmilla appeared in the castle, Laura is visited by a black macabre cat-like creature. The mystical animal walks to and fro in her room, and then suddenly bites the girl's breast. Here we can see old prejudices against night animals that were considered to foretell death, and belief in familiar spirits, that follow witches and «cunning folk» (practitioners of folk medicine and magic) and assist them usually turning into a black cat, an owl or another animal [7, p. 46-53]. Differently from the 
folklore vampire, who always appears as a walking corpse, Carmilla can morph into an animal or even an amorphous pulsating substance dissolving in the air and possesses supernatural physical fortitude, all of these things make her elusive and very dangerous super-being. The only way to defeat her is to find her grave.

Fears underlying the basis of primaeval humans' safety, like fear of darkness, natural forces, loneliness, of wild animals, were transformed in cultural fears like those of supernatural creatures, unfamiliar or strange objects and people. It is at night that a human being becomes helpless, and ghosts and vampires come to power. Supernatural creatures in horror fiction can change their victim's state of consciousness, as Carmilla did. Both Laura and Bertha (the previous victim of Carmilla) see nightmares first and then are visited by a mysterious creature, without being sure it was a dream. Bertha's caretaker General Spielsdorf describes her strange disease as follows:

«My dear child began to lose her looks and health, and that in a manner so mysterious, and even horrible, that I became thoroughly frightened.

She was at first visited by appalling dreams; then, as she fancied, by a spectre, sometimes resembling Millarca, sometimes in the shape of a beast, indistinctly seen, walking round the foot of her bed, from side to side» [5, p. 259].

In this abstract we can notice the chain of words, related to the emotional row of fear: «mysterious», «horrible», «frightened», «appalling», and the objects of fear, «spectre» and «beast», the latter meaning not just an animal but a brute, wild, cruel and dangerous.

As can be seen from the above, natural fear of human beings for death and everything threatening their lives is the target for horror fiction. The emotion of fear is created with the help of lexico-stylistic means that transfer the feeling of danger, obscureness and suspense. The categories of horrible and mysterious are closely connected in horror fiction, as mysterious things and events bear danger for the protagonist's life and thus evolve fear.

\section{References}

1. Burke, E. (1968). A Philosophical Enquiry 4. Kristeva, J. (1982). Powers of horror into the Origin of Our Ideas of the sublime and Beautiful. Ed. James T. Boulton. Notre Dame: University of Notre Dame Press.

2. Freud, S. (2004). The uncanny. In S. Freud. Literary Theory: An Anthology. (pp. 418430). Maiden: Blackwell Publishing.

3. Kaplama, E. (2016). Kantian and nietzschean aesthetics of human nature: a comparison between the beautiful/sublime and Apollonian/Dionysian dualities. Cosmos and History: The Journal of Natural and Social Philosophy, 12(1), 166-217. (Vol. 98). University Presses of California, Columbia and Princeton.

5. Le Fanu, J. S. (2008). Carmilla. In J. S. Le Fanu, In a Glass Darkly (pp. 207-272). Ware: Wordsworth Editions.

6. Rosenkranz, K. (2015). Aesthetics of ugliness: A critical edition. Bloomsbury Publishing.

7. Wilby, E. (2005). Cunning folk and familiar spirits: shamanistic visionary traditions in early modern British witchcraft and magic. ISBS.

Надійшла до редакиії 18.10.2019 